\title{
Multiple-Platform and Multiple-Doppler Radar Observations of a Supercell Thunderstorm in South America during RELAMPAGO
}

\author{
Robert J. Trapp, ${ }^{a}$ KARen A. Kosiba, ${ }^{\mathrm{b}}$ JAmes N. MARquis, ${ }^{\mathrm{c}}$ MATthew R. Kumjian, ${ }^{\mathrm{d}}$ \\ Stephen W. Nesbitt, ${ }^{\mathrm{a}}$ Joshua Wurman, ${ }^{\mathrm{b}}$ PaOla SAlio, ${ }^{\mathrm{e}}$ MaXwell A. Grover, ${ }^{\mathrm{a}}$ \\ PAUl ROBINSON, ${ }^{\mathrm{b}}$ AND DEANNA A. HENCE ${ }^{\mathrm{a}}$ \\ ${ }^{a}$ Department of Atmospheric Sciences, University of Illinois at Urbana-Champaign, Urbana, Illinois \\ ${ }^{\mathrm{b}}$ Center for Severe Weather Research, Boulder, Colorado \\ ${ }^{\mathrm{c}}$ Pacific Northwest National Laboratory, Richland, Washington, and University of Colorado Boulder, Boulder, Colorado \\ ${ }^{\mathrm{d}}$ Department of Meteorology and Atmospheric Science, The Pennsylvania State University, University Park, Pennsylvania

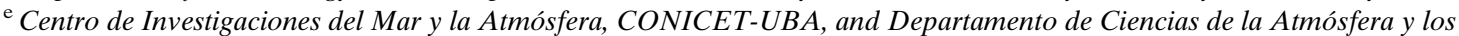 \\ Océanos, UBA, UMI-IFAECI, CNRS-CONICET-UBA, Buenos Aires, Argentina
}

(Manuscript received 20 April 2020, in final form 18 May 2020)

\begin{abstract}
On 10 November 2018, during the RELAMPAGO field campaign in Argentina, South America, a thunderstorm with supercell characteristics was observed by an array of mobile observing instruments, including three Doppler on Wheels radars. In contrast to the archetypal supercell described in the Glossary of Meteorology, the updraft rotation in this storm was rather short lived ( $\sim 25 \mathrm{~min})$, causing some initial doubt as to whether this indeed was a supercell. However, retrieved 3D winds from dual-Doppler radar scans were used to document a high spatial correspondence between midlevel vertical velocity and vertical vorticity in this storm, thus providing evidence to support the supercell categorization. Additional data collected within the RELAMPAGO domain revealed other storms with this behavior, which appears to be attributable in part to effects of the local terrain. Specifically, the IOP4 supercell and other short-duration supercell cases presented had storm motions that were nearly perpendicular to the long axis of the Sierras de Córdoba Mountains; a long-duration supercell case, on the other hand, had a storm motion nearly parallel to these mountains. Sounding observations as well as model simulations indicate that a mountain-perpendicular storm motion results in a relatively short storm residence time within the narrow zone of terrain-enhanced vertical wind shear. Such a motion and short residence time would limit the upward tilting, by the left-moving supercell updraft, of the storm-relative, antistreamwise horizontal vorticity associated with anabatic flow near complex terrain.
\end{abstract}

\section{Introduction}

Satellite observations suggest that thunderstorms in southeast South America are among the most intense and deepest in the world (Zipser et al. 2006), are prolific hail producers (Cecil and Blankenship 2012; Mezher et al. 2012; Bang and Cecil 2019; Bruick et al. 2019), and often are accompanied by extreme lightning activity and flooding (e.g., Rasmussen et al. 2014). In Argentina specifically, thunderstorm-generated hazards adversely impact a largely urban population of 45 million people, yet the thunderstorm-generated rainfall is also critical for agricultural production, which is one of the country's economic pillars. Such impact, the high frequency of convection

Corresponding author: Robert J. Trapp, jtrapp@illinois.edu initiation (CI) and subsequent development of hazardous weather over a relatively small area in Argentina as compared to that of the U.S. Great Plains, and relatively sparse knowledge about these convective storms owing to the scarcity of ground-based measurements, motivated the Remote sensing of Electrification, Lightning, And Mesoscale/microscale Processes with Adaptive Ground Observations (RELAMPAGO) field program, funded primarily by the National Science Foundation (Nesbitt et al. 2016), and the complementary Clouds, Aerosols, and Complex Terrain Interactions (CACTI) field program funded by the Department of Energy Atmospheric Radiation Measurement (DOE-ARM) program (https://www.arm.gov/publications/programdocs/ doe-sc-arm-19-028.pdf). The detailed justification for RELAMPAGO-CACTI, as well as a comprehensive 


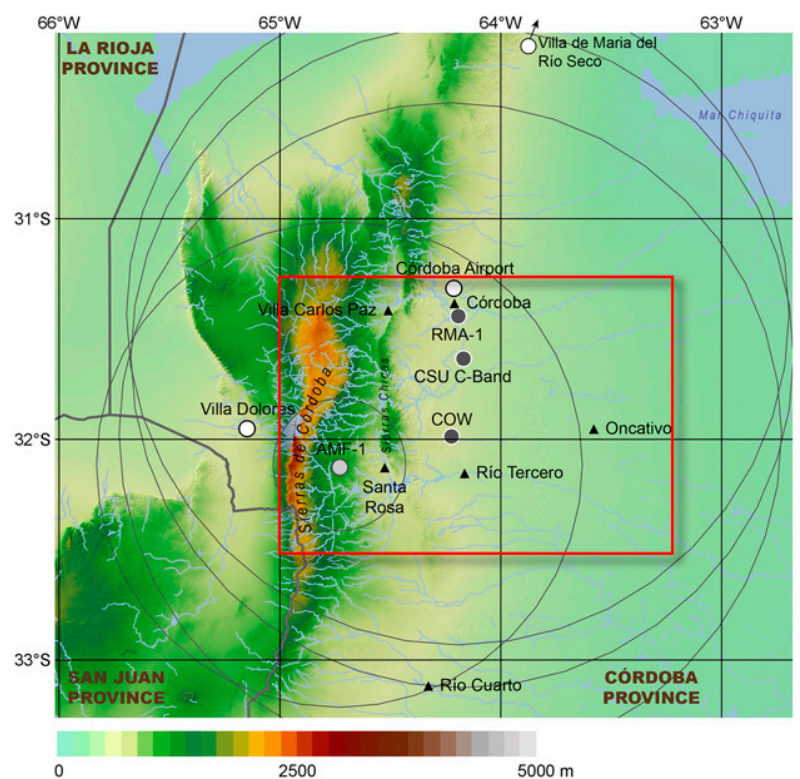

FIG. 1. Overview of RELAMPAGO-CACTI observational domain in Córdoba. Fixed radars are indicated with dark gray circles [with $150-\mathrm{km}$ range rings except for a $115-$ and $25-\mathrm{km}$ range ring from the DOE second generation C-band Scanning ARM Precipitation Radar (CSAPR2) and Scanning Arm Cloud Radar (SACR), respectively]. Light gray circle is the location of the DOE-ARM CACTI site, where the CSAPR2 and SACR were located. White circles are the location of fixed sounding sites. Triangles indicate cities or villages of relevance to the article. Red box indicates the subdomain shown in Fig. 4.

review of the supporting literature, can be found in Nesbitt et al. (2016) and Varble et al. (2018).

The field phase of RELAMPAGO was conducted from 1 November-16 December 2018, over two relatively small (approximately $1^{\circ}$ latitude $\times 1^{\circ}$ longitude) domains: west central Argentina in the general vicinity of the Sierras de Córdoba mountains (hereinafter, SDC; Fig. 1), and the Andes foothills near San Rafael, in the Mendoza Province. Integrated, targeted groundbased instrumentation sampled the local mesoscale environment as well as internal convective-storm processes. The instrumentation included a network of three X-band (3-cm wavelength) Doppler on Wheels (DOW) mobile radars (Wurman et al. 1997; Wurman 2001), one C-band (5-cm wavelength) On Wheels portable radar (COW), one C-band fixed-site radar (CSU C-band), six mobile radiosonde systems, three "mobile mesonet" vehicles (MMs), which were also tasked with the deployment of up to 12 portable surface weather stations (Pods) and up to four disdrometers, and hail pads.

Based on the analysis of Mulholland et al. (2018), the field phase of RELAMPAGO corresponded to the time interval over which supercell thunderstorms are most prone to occur within southeast South America. In the United States, supercells are nearly always associated with some form of severe convective weather (e.g., Smith et al. 2012), and more specifically, are the likely generators of large and extreme hail (e.g., Blair et al. 2017). From available data, this latter attribute appears to apply to South American supercells as well (C. Elkins 2019, personal communication; Kumjian et al. 2020). Supercells in southeast South America are also frequent precursors to mesoscale convective systems (MCSs) (Mulholland et al. 2018) via an "upscale growth" process not yet fully understood (Mulholland et al. 2019). The heavy rainfall from the resultant MCSs often leads to riverine and flash flooding (e.g., Rasmussen et al. 2014).

On 10 November 2018, an upper-level trough approached the SDC domain and contributed to the environmental vertical wind shear and convective instability (e.g., Chisholm and Renick 1972; Weisman and Klemp 1982) necessary for the development of an intense convective storm with supercellular characteristics. In section 2 of this article, we will describe the planning and execution of the observing strategy used during the RELAMPAGO Intensive Observational Period (IOP) 4 to sample this convective storm. This is (believed to be) the first set of supercell data collected by a network of multiple Doppler radars and integrated surface instrumentation in South America, and is one of perhaps two such datasets collected in the Southern Hemisphere (Krupar et al. 2017; also Soderholm et al. 2016). A summary of storms and strategies during the other RELAMPAGO IOPs will be provided in a project-overview article in preparation for the Bulletin of the American Meteorological Society; the current article will focus specifically on the IOP4 supercell.

As we will show in section 3, the IOP4 storm possessed a midlevel mesocyclone and a "hook echo" in radar reflectivity, and also exhibited a motion that deviated from the mean environmental wind. These are considered hallmarks of the supercell morphology (e.g., American Meteorological Society 2020). However, as confirmed by multiple-Doppler wind analyses, the mesocyclone was relatively short lived $(\sim 25 \mathrm{~min})$, leading us to debate whether this storm conforms to the accepted conceptual model and definition (e.g., American Meteorological Society 2020). We will draw on additional analyses as well as the model simulations by Mulholland et al. (2019) to help us understand how the local terrain may have influenced the observed evolution. To provide context to this case, we will also briefly describe in section 4 other events within the Córdoba Province that had a similar convective 

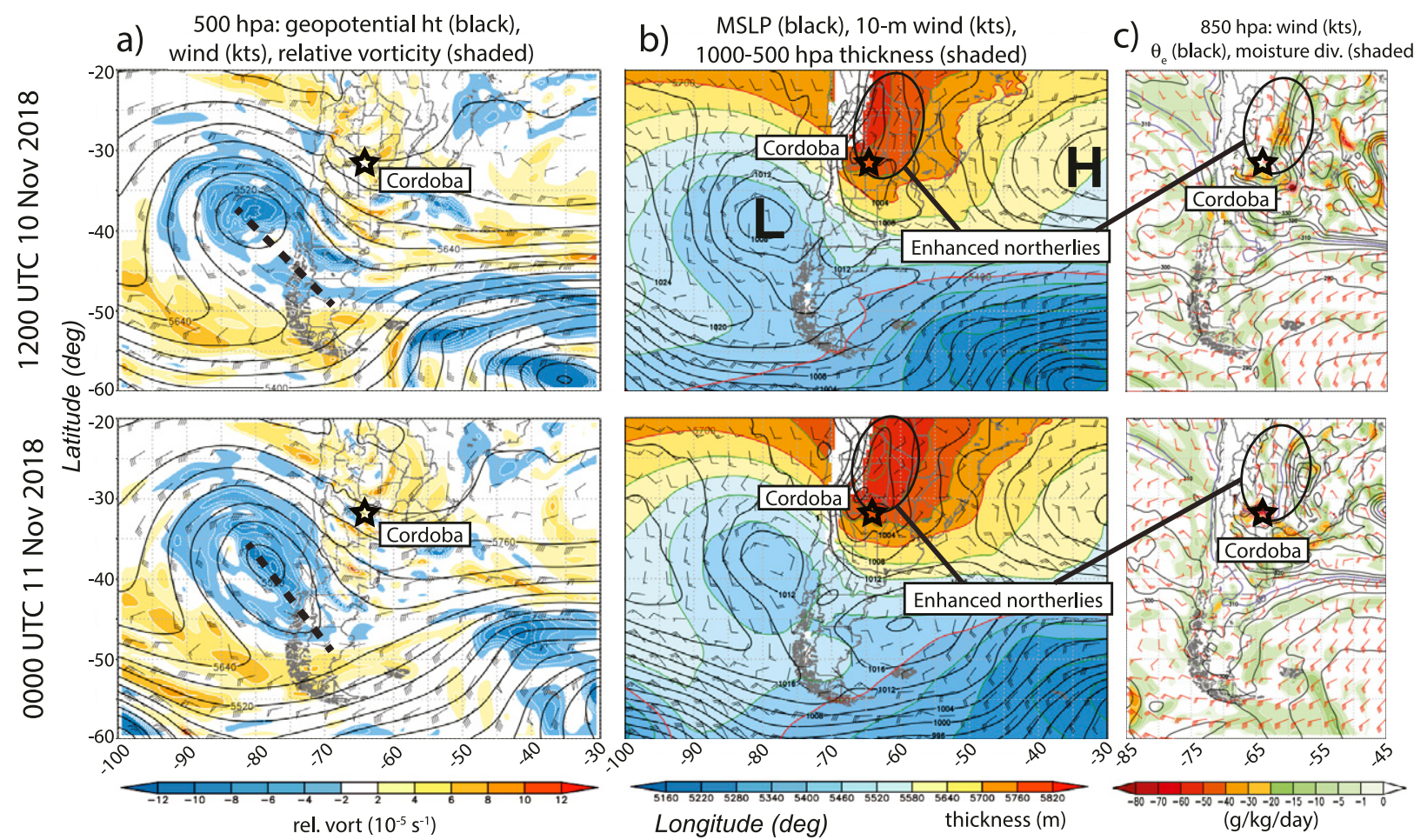

FIG. 2. (a) 500-hPa analyses, (b) sea level pressure, and (c) 850-hPa analyses based on 0-h forecasts of the Global Forecast System, valid at (top) 1200 UTC 10 Nov and (bottom) 0000 UTC 11 Nov 2018.

morphology and evolution. Finally, in section 5, we will summarize our findings and discuss future research directions with this novel dataset.

\section{Observational-strategy planning and execution during intensive observational period 4}

\section{a. Overview of relevant meteorology and forecast process}

The axis of a vigorous upper-level trough over the Pacific Ocean was positioned just upstream of the Andes Mountains at 1200 UTC 10 November 2018, and slowly progressed eastward during the day. A strong $\left(>25 \mathrm{~m} \mathrm{~s}^{-1}\right)$ northwesterly jet at $500 \mathrm{hPa}$ extending across Córdoba Province (Fig. 2a) was associated with this trough. Interaction of this northwesterly flow with the Andes Mountains induced a northern Argentinean low (Seluchi et al. 2003) (Fig. 2b) that, in concert with the subtropical high over the Atlantic Ocean, enhanced low-level northerly flow throughout the day. At $850 \mathrm{hPa}$, this northerly flow was in the form of a South American low-level jet (SALLJ; e.g., Salio et al. 2002) (Fig. 2c). The resulting vertical wind profile was characterized by $0-6 \mathrm{~km}$ vertical wind shear (S06) of $\sim 25 \mathrm{~m} \mathrm{~s}^{-1}$, and 0-3 km storm-relative environmental helicity (SRH) of $\sim-200 \mathrm{~m}^{2} \mathrm{~s}^{-2}$, which are considered supportive of supercellular convection in this region (e.g., Mulholland et al. 2018) and elsewhere around the world.

The quasigeostrophic vertical motion associated with the trough, in combination with differential temperature advection, led to steep midtropospheric lapse rates across much of Córdoba Province. These lapse rates and the low-level moisture transport by the SALLJ resulted in surface-based convective available potential energy (SBCAPE) of $\sim 2800 \mathrm{~J} \mathrm{~kg}^{-1}$ at $1200 \mathrm{UTC}$, as measured at multiple sites across the SDC domain; this included the CACTI AMF-1 site (Fig. 3), which was located within the SDC (Fig. 1) and thus in the vicinity of CI preceding the IOP4 storm. The occurrence of supercellular convection in this environment of high CAPE is consistent with the composite analysis of Mulholland et al. (2018).

One of the forecast uncertainties during IOP4 was the geographical location and timing of the initiation of deep convection, especially given the strength of the capping inversion and associated convective inhibition (CIN) present in the 1200 UTC soundings (Fig. 3). Parcel lifting was expected in association with horizontal moisture convergence along an east-west-oriented mesoscale boundary south of the observing domain. The low-level flow north of the boundary had a northeasterly (i.e., upslope) component, which was also expected to 


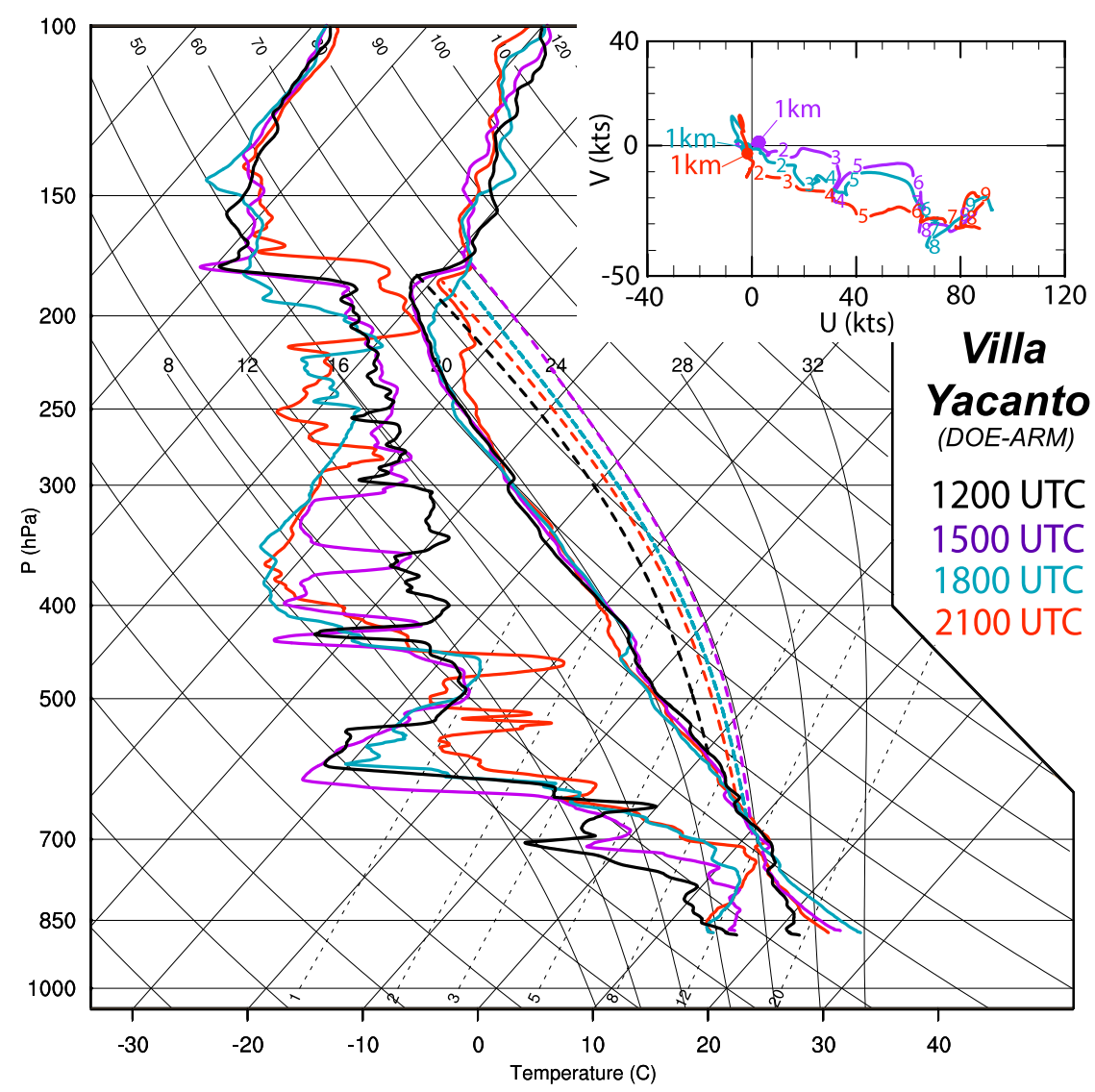

FIG. 3. Skew $T-\log p$ diagram and hodograph (insert in upper right) based on radiosondes launched from the DOE-ARM CACTI site at Villa Yacanto (valid near the CI location) at four times throughout 10 Nov 2018. Properties of a lifted parcel representative of an average of the lowest $100-\mathrm{hPa}$ of the atmosphere from each sounding are shown with dotted lines.

aid CI, as was a northward surging cold pool generated by convective storms ongoing during the morning. However, the forecasted evolution of the boundary, terrain, and cold pool interactions relative to the evolution of CAPE and CIN was rather complex.

The observational-strategy planning for IOP4 was further complicated by the operational constraint that the mobile radars needed to be stationary during IOPs, and deployed only to predetermined sites anchored to a limited all-weather road network. Guidance for such planning was provided in part by global forecast models such as the NOAA Global Forecast System (GFS), but these models lack the granularity needed for the precise deployment decisions. Accordingly, convection-allowing models (CAMs), which have typical horizontal gridpoint spacings of a few kilometers, were relied upon heavily: real-time, 48-h CAM forecasts were generated by three participating institutions, using regional configurations of the Weather Research and Forecasting (WRF) Model (e.g., Skamarock et al. 2008). Additionally, a 96-h forecast was generated using the
Model for Prediction Across Scales (MPAS) (Skamarock et al. 2012), in a $15-3 \mathrm{~km}$ configuration, such that the computational mesh for the entirety of the South American continent had 3-km gridpoint spacing. It is noteworthy that the simulated reflectivity factor and updraft helicity fields (not shown) in the 90-h MPAS forecast (valid 1800 UTC 10 November 2018) exhibited discrete cells with supercell characteristics in the vicinity of Rio Tercero and Rio Cuarto (Fig. 1). The 48-h WRF forecasts similarly exhibited discrete cells in this general geographic area, providing sufficient confidence in the deployment strategy described next.

\section{b. Deployment strategy}

Mobile teams departed Villa Carlos Paz, the RELAMPAGO operations base, by $\sim 1200$ UTC to a domain roughly centered at $31.86^{\circ} \mathrm{S}, 64.09^{\circ} \mathrm{W}$ (Fig. 4). The primary objectives of this deployment were to (i) collect dual-Doppler data on anticipated supercellular storm formation, with a specific focus on up/downdraft structure and intensity, (ii) collect in situ and radar data in the cold pools associated 


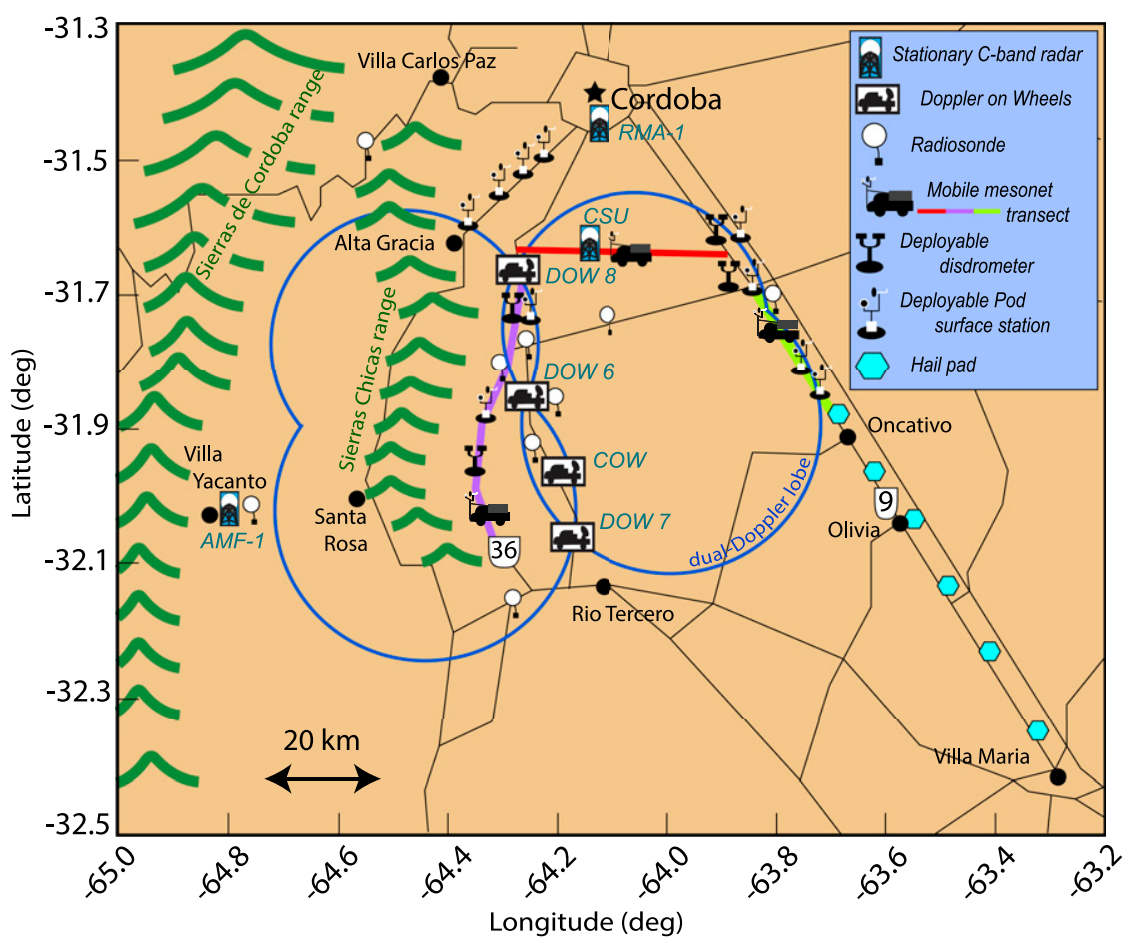

FIG. 4. Deployment strategy for IOP4. Symbols for the mobile and stationary assets are defined in the inset.

with the supercells and other convective storms, and (iii) sample the near-storm environment throughout storm evolution via high-frequency sounding launches.

As depicted in Fig. 4, the three DOWs were configured in an approximately north-south line, north of Rio Tercero, with radar separations, or baselines, of $\sim 25 \mathrm{~km}$. The MMs, which were crewed by Center for Severe Weather Research (CSWR) personnel, performed transects primarily along Hwy 36 and Hwy 9. Pods were deployed along these highways, with an approximate $7-\mathrm{km}$ spacing. MM transects and pod deployments were designed to measure storm-relative inflow and surface cold pool characteristics. An additional west-east MM transect was performed to sample ground-relative inflow into storms forming to the south. Between transects, the MM teams launched hourly soundings beginning at 1600 UTC in order to sample the prestorm and then near-storm environments. One of the University of Illinois sounding teams launched hourly soundings beginning at 1600 UTC, at a high-elevation location $\left(31.541^{\circ} \mathrm{S}, 64.604^{\circ} \mathrm{W}\right)$ to meet an additional RELAMPAGO science objective aimed at understanding upscale growth of convective storms. Soundings by the other University of Illinois team and the Colorado State University team were designed to be highly adaptive: their respective tasks were to collect high-frequency ( $\sim 30-\mathrm{min})$ truncated soundings within cold pools and within targeted convective updrafts and inflow. Prior to these high-frequency launches, these teams launched soundings to characterize the background environment. Finally, hail pads were deployed by the Penn State University hail team along Highway 9, with a $\sim 15 \mathrm{~km}$ spacing.

\section{Observations of a South American supercell}

\section{a. Overview of convection initiation and subsequent evolution}

The IOP4 supercell appears to have originated from a complex series of interactions involving the local terrain and convectively generated cold pools from ongoing deep convective storms. The first of these storms initiated southwest of San Luis at 2200 UTC 9 November 2018 , and thus nearly one day prior to IOP4 operations. This was followed by the initiation of an additional storm at $\sim 0000$ UTC 10 November 2018 over the Andes foothills near Mendoza (Fig. 5a). Both of these storms ultimately contributed to the formation of a nocturnal MCS that moved toward the southeast, in the wake of an even more intense nocturnal MCS that affected the region southeast of the RELAMPAGO domain (Fig. 5b). A combination of this MCS and associated early morning backbuilding of convection (Fig. 5c) generated a 

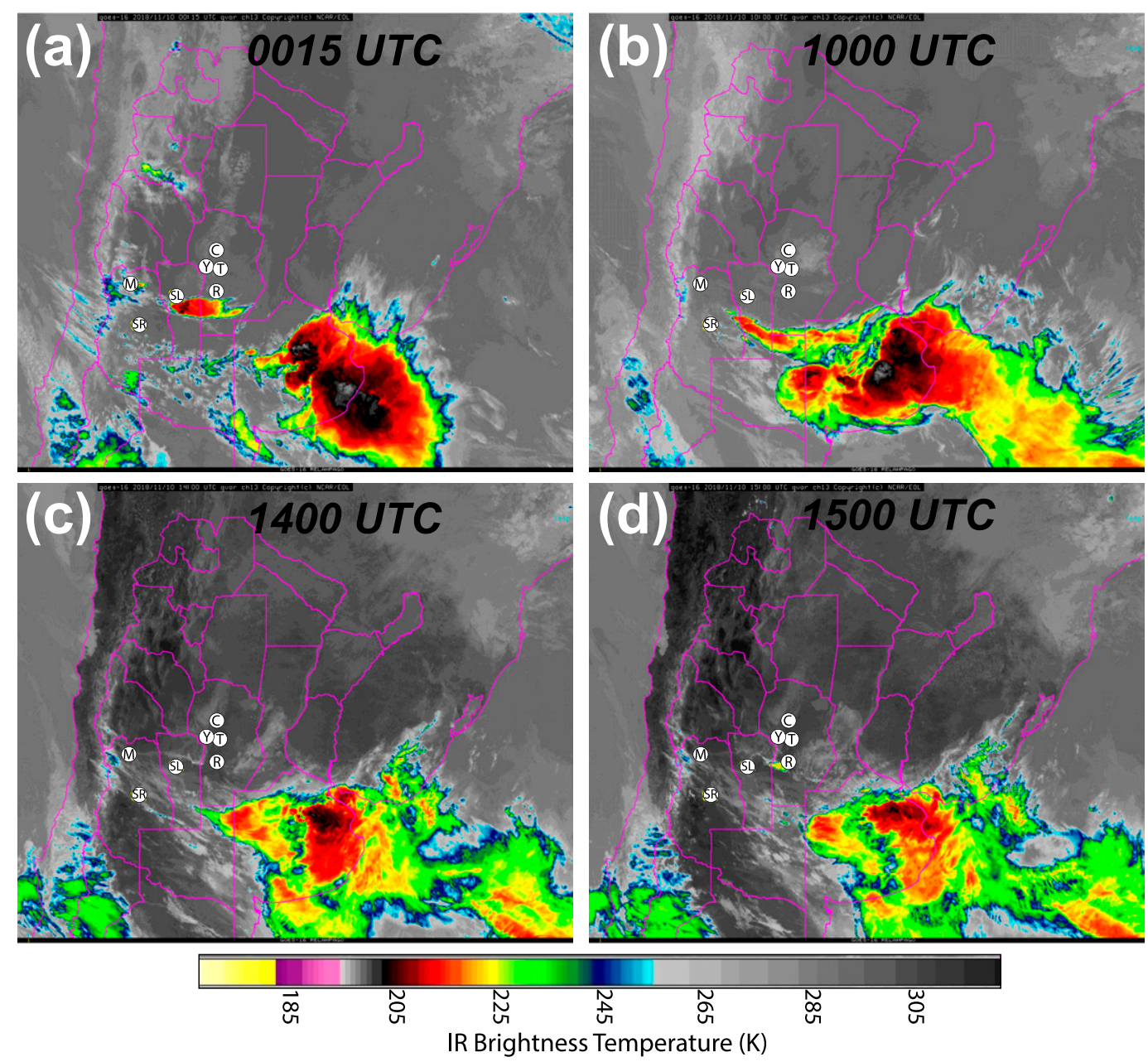

FIG. 5. GOES-16 infrared satellite imagery sequence leading up to the CI of the IOP4 storm: (a) 0015, (b) 1000, (c) 1400, and (d) 1500 UTC 10 Nov 2018. Cordoba (C), Rio Tercero (T), Rio Cuarto (R), Villa Yacanto (Y), Mendoza (M), San Luis (SL), and San Raphael (SR).

northward-moving cold pool that served as a triggering mechanism for new storms between San Luis and Rio Cuarto in the early afternoon, $\sim 1500$ UTC (Fig. 5d). Development of deep convection near Rio Cuarto yielded a second prominent northward-moving cold pool (Fig. 6a) that led to CI of the storm described herein, at approximately 1900 UTC near Santa Rosa, between Villa Yacanto and Rio Tercero (Fig. 6b).

Further documentation of the evolution of the convective potential throughout the day, and of the mesoscale processes that helped to realize this potential, is provided by the CACTI assets, which were positioned in the SDC approximately $20 \mathrm{~km}$ west of the CI location. Radiosondes launched at the CACTI site at 3-h frequency (ARM 2018a) show that 100-hPa mixed-layer (ML) CAPE was approximately $2900 \mathrm{~J} \mathrm{~kg}^{-1}$ by $1500 \mathrm{UTC}$, with approximately $50 \mathrm{~J} \mathrm{~kg}^{-1}$ of mixed-layer convective inhibition (MLCIN). These values remained mostly unchanged by 1800 UTC, which was about $45 \mathrm{~min}$ before passage of the CI-triggering gust front, and $1-1.25 \mathrm{~h}$ before CI itself. A few hours after the gust front passed the CACTI site (e.g., 2100 UTC in Fig. 3), the boundary layer remained well-mixed owing to clearing skies over the cold pool, albeit with cooler temperatures overall, yielding 120 and $2140 \mathrm{~J} \mathrm{~kg}^{-1}$ of MLCIN and MLCAPE, respectively.

Data collected from the 2nd generation C-band Scanning ARM Precipitation Radar (CSAPR2; ARM 2018b), located at the CACTI AMF-1 site, support the satellite-based attribution of CI to lifting of boundary layer parcels by the northward-moving cold-pool gust front generated by preceding convection to the south (Fig. 7), although it should be noted that CI also occurred near elevated terrain along the Sierras Chicas between Villa Yacanto and Rio Tercero (Fig. 4); thus, orographic effects may have aided in CI processes. 


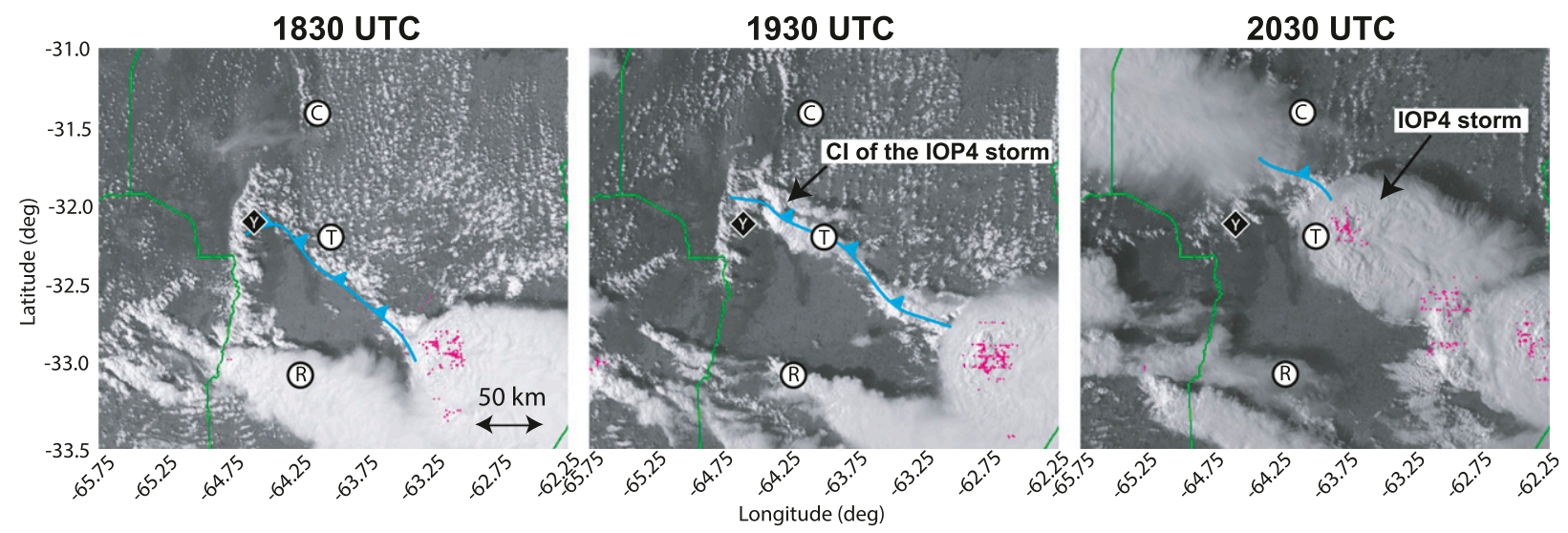

FIG. 6. GOES-16 visible satellite imagery sequence from pre-CI through the maturing stage of the IOP4 storm. Lightning strikes are shown with purple dots. Position of a northward-moving gust front, which triggered CI of the IOP4 storm, is illustrated in each panel. Cordoba (C), Rio Tercero (T), Rio Cuarto (R), and Villa Yacanto (Y; the approximate launch location of radiosondes shown in Fig. 3) also are shown in each panel.

Range-height indicator (RHI) scans conducted by CSAPR 2 at $30^{\circ}$ azimuth increments captured the rapid vertical growth of the deep convection, which reached $\sim 12 \mathrm{~km}$ altitude within $\sim 30 \mathrm{~min}$ from the time of the first detected echoes (Fig. 7). Select RHIs also captured turbulent eddies within the cloud during the intensification of the storm, including two large $[O(1) \mathrm{km}]$ eddies on both sides of the apparent updraft region. These turbulent eddies resemble toroidal circulations associated with buoyant updraft thermals in high-resolution simulations and observations (e.g., Zhao and Austin 2005; Blyth et al. 2005; Damiani et al. 2006; Morrison 2017). Many studies link such eddies with entrainment of environmental air into the updraft. Additional partly resolved smaller-scale $[O(100) \mathrm{m}]$ eddies seen within and at the top of the updraft likely also play roles in updraft and cloud entrainment. The interactions between such observed features and the environment during CI are being pursued by the coauthors among the RELAMPAGO-CACTI cases.

Within 1 to $1.5 \mathrm{~h}$, the newly initiated deep convection moved off the terrain and evolved rapidly into a convective storm with supercell characteristics (Figs. 6c, 8a). The storm motion at about this time (2000 UTC) was approximately $13 \mathrm{~m} \mathrm{~s}^{-1}$ from the west, and thus "left" of the mean environmental wind (Fig. 3); this is consistent with a "left-moving," cyclonically rotating ${ }^{1}$ supercell (e.g., Klemp and Wilhelmson 1978). Indeed, midlevel ( $\sim 3-5 \mathrm{~km}$ AGL) mesocyclonic rotation was observed in DOW scans by $\sim 1955$ UTC, and then by 1957 UTC in scans of the more distant Radar Meteorológico

\footnotetext{
${ }^{1}$ Note that in the Southern Hemisphere, clockwise rotation is considered cyclonic.
}

Argentino 1 (RMA1), a C-band Doppler radar located in Ciudad Universitaria, in the city of Córdoba (Fig. 1). The midlevel mesocyclone intensified thereafter, and persisted until $\sim 2020$ UTC; a hook echo in radar reflectivity was also present during this period (Fig. 8a). Absent in this case is any evidence of mesocyclonic rotation at or below $\sim 1 \mathrm{~km}$ AGL (hereinafter, "low-level"), although this would appear to be consistent with the relative lack of environmental vertical wind shear at low levels (Fig. 3). The relative abundance of parcel buoyancy and high CAPE (Fig. 3), on the other hand, was realized through an updraft associated with a prominent echo overhang and echo-top heights of nearly $17 \mathrm{~km}$ (Fig. 9). Substantial overshooting tops in GOES-16 IR imagery are also found (not shown); Trapp et al. (2017) have hypothesized a connection between overshooting-top area with low- and midaltitude updraft area (Marion et al. 2019), and quantifications of both will be conducted in the future to address this connection and associated dynamics.

\section{b. Hail generation in the IOP4 supercell}

Shortly before 2000 UTC, the storm produced large hail (Figs. 10a,b) that damaged the antenna of the yetto-be-assembled COW radar (Fig. 10c; also Fig. 1). Photographs of the hail taken at 2037 UTC (Figs. 10a,b), nearly $40 \mathrm{~min}$ after the hail fell, still revealed stones $>4-5 \mathrm{~cm}$. Hail in excess of $5 \mathrm{~cm}$, which is considered "significantly severe" by the U.S. National Weather Service, is common in the vast majority $(\sim 90 \%)$ of supercell storms, at least in the U.S. Great Plains (Blair et al. 2017); this case is consistent with those findings.

Preliminary insight into hail generation by the IOP4 supercell is provided by dual-frequency, dual-polarization 

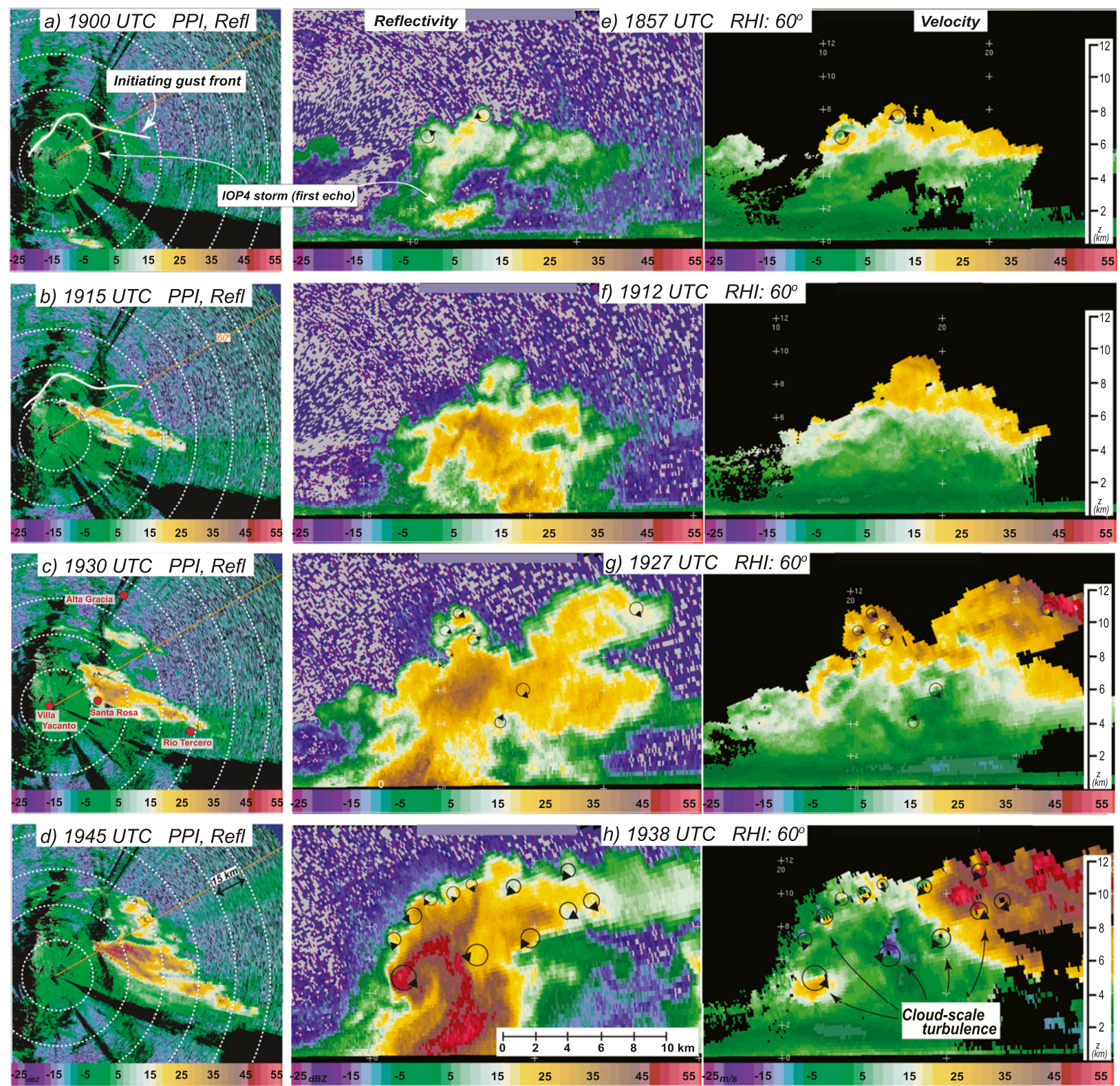

FIG. 7. (left) CSAPR2 reflectivity (dBZ) PPI scans and (right) RHI scans of reflectivity (dBZ) and radial velocity (m s ${ }^{-1}$ ) during the initiation sequence of the IOP4 storm. Cloud-scale turbulent rotors, subjectively identified with Doppler radial velocity couplets, are illustrated with rings.

data collected by DOW6 and DOW7. Low-level planposition indicator (PPI) scans from DOW6 collected at 2010 UTC, and thus shortly after damaging hail was observed at the COW location, are shown in Fig. 8. Classic supercell polarimetric radar characteristics are evident, including a differential reflectivity $\left(Z_{\mathrm{DR}}\right)$ arc (Kumjian and Ryzhkov 2008), despite significant attenuation and differential attenuation that is evident through the heavy precipitation cores (Figs. 8a,b). There is also a region of reduced $Z_{\mathrm{DR}}$ just south of the updraft, in a preferred region for hail fallout. This region is collocated with reduced copolar cross-correlation coefficient $\left(\rho_{\text {hv }}\right)($ Fig. 8e), significant backscatter differential phase (Fig. 8d), and enhanced linear depolarization ratio (LDR) (Fig. 8f). These dual-polarization radar signatures are consistent with the presence of large, nonspherical hail, and may be an indication of ongoing severe hail production. Owing to size sorting, trajectories of smaller hailstones would be expected to fallout farther west of this location and of the cyclonic shear zone delineating the rear- and forwardflank precipitation cores (Fig. 8c). This region is precisely where substantial differential attenuation (Fig. 8b) and 

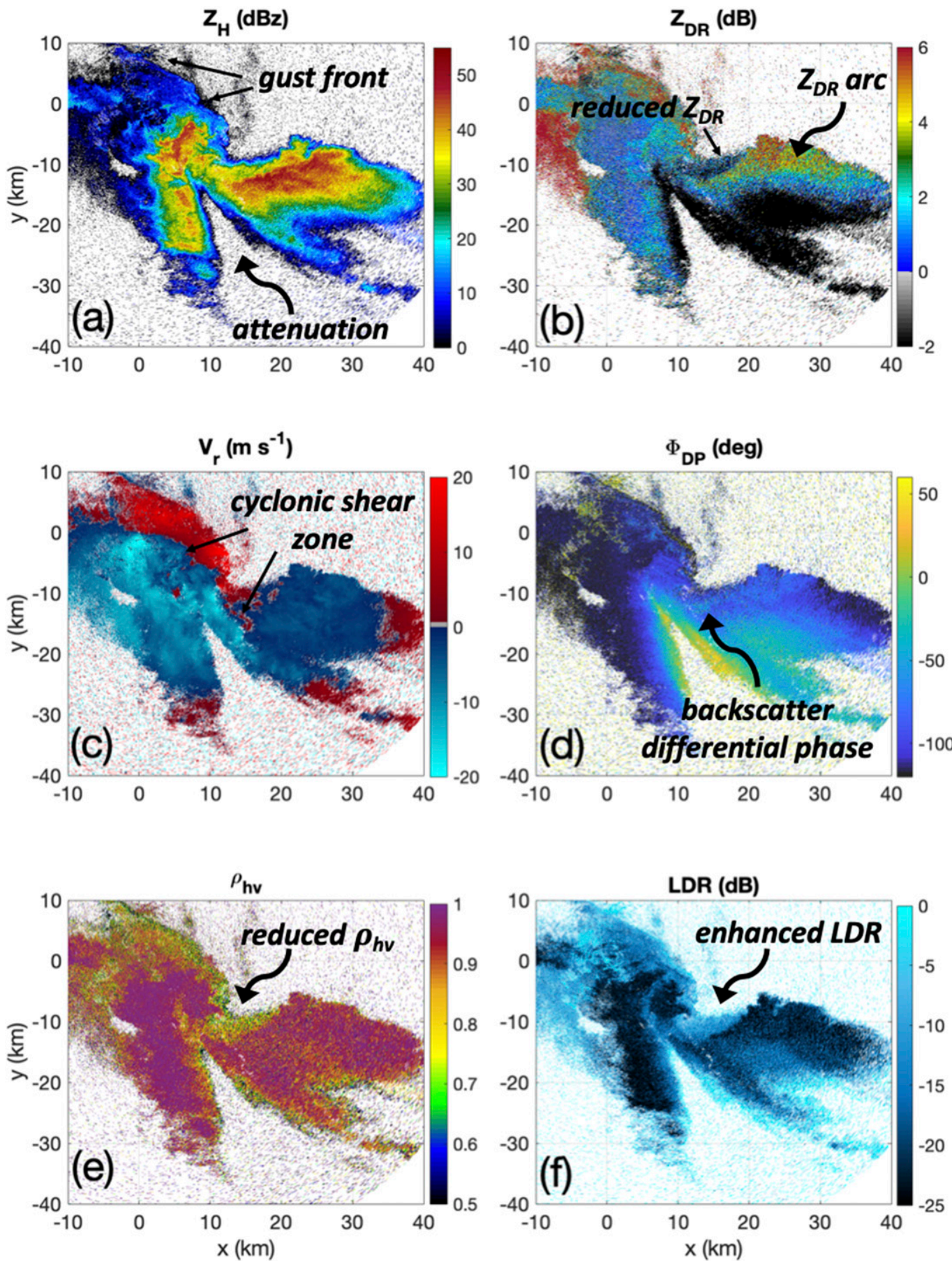

FIG. 8. 4.0 elevation angle PPI scans from DOW6 at 2010:54 UTC 10 Nov 2018. Fields shown are (a) reflectivity factor at horizontal polarization $\left(Z_{H}\right)$, (b) differential reflectivity $\left(Z_{\mathrm{DR}}\right)$, (c) Doppler velocity $\left(V_{r}\right)$, (d) differential phase shift $\left(\Phi_{\mathrm{DP}}\right)$, (e) copolar cross-correlation coefficient $\left(\rho_{\mathrm{hv}}\right)$, and (f) linear depolarization ratio (LDR). Annotated features are described in the text.

accumulation of differential phase shift $\left(\Phi_{\mathrm{DP}}\right)($ Fig. $8 \mathrm{~d})$ are found, indicating the presence of large raindrops (i.e., entirely melted hailstones) and small, melting hail (e.g., Ryzhkov et al. 2013; Kumjian et al. 2019).
Between 2050 and 2115 UTC, the storm moved across the array of hailpads set up by the Penn State University hail team (Fig. 4). Several of the hailpads registered hail impacts with estimated largest sizes close to $2 \mathrm{~cm}$. 


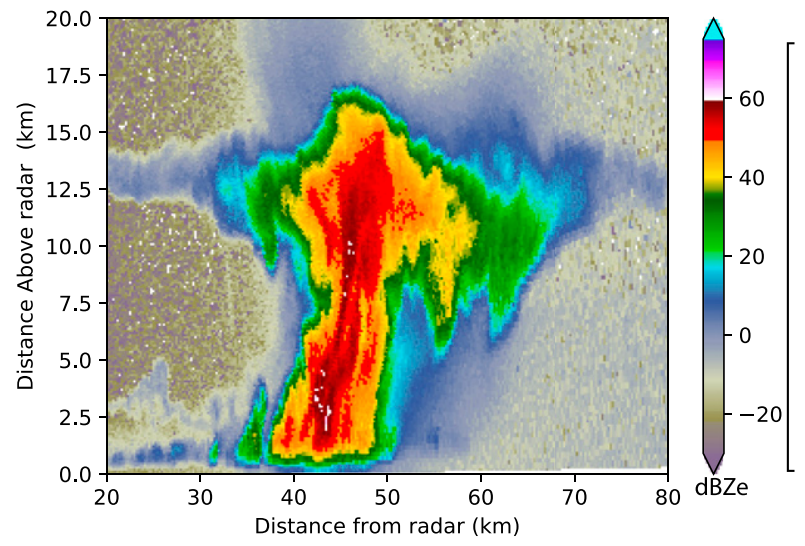

FIG. 9. CSU C-band equivalent radar reflectivity $\left(\mathrm{dB} Z_{e}\right)$ in an RHI scan at 2023:08 UTC 10 Nov 2018. The radar azimuth of the scan is $172^{\circ}$.

Social media postings revealed somewhat larger hail $(3-4 \mathrm{~cm})$ in Oncativo, closer to the core of the storm. The hail team intercepted the storm's right flank near Oliva (to the southeast of Oncativo) and received a few stones in situ, including one measuring $3.2 \mathrm{~cm}$ in maximum dimension (not shown). This overall decrease in maximum hail size is consistent with the more marginal supercellular characteristics the storm displayed on radar at this time. After the storm passed Oncativo, the Penn State University team's hail survey did not identify any hail damage or hailstones. The storm then moved out of the RELAMPAGO domain.

\section{c. Supercell structure from dual-Doppler radar analysis}

The onset of hail at $\sim 2000$ UTC also corresponded to the approximate time at which the storm entered one of the dual-Doppler lobes comprised by DOW6 and DOW 7 (Fig. 4). The 3D winds retrieved from the dual-Doppler radar data reveal well the structure and evolution of the IOP4 supercell. Briefly, the dual-Doppler retrievals follow the methodology described by Kosiba et al. (2013). DOW data were objectively analyzed to a Cartesian grid using a twopass Barnes scheme (Majcen et al. 2008) and an isotropic smoothing parameter of $0.03 \mathrm{~km}^{2}$. A horizontal grid spacing of $200 \mathrm{~m}$ was chosen to match the sampling interval at $15 \mathrm{~km}$ range. During the supercell occurrence, the low-level sweeps by DOW6 and DOW7 were slightly

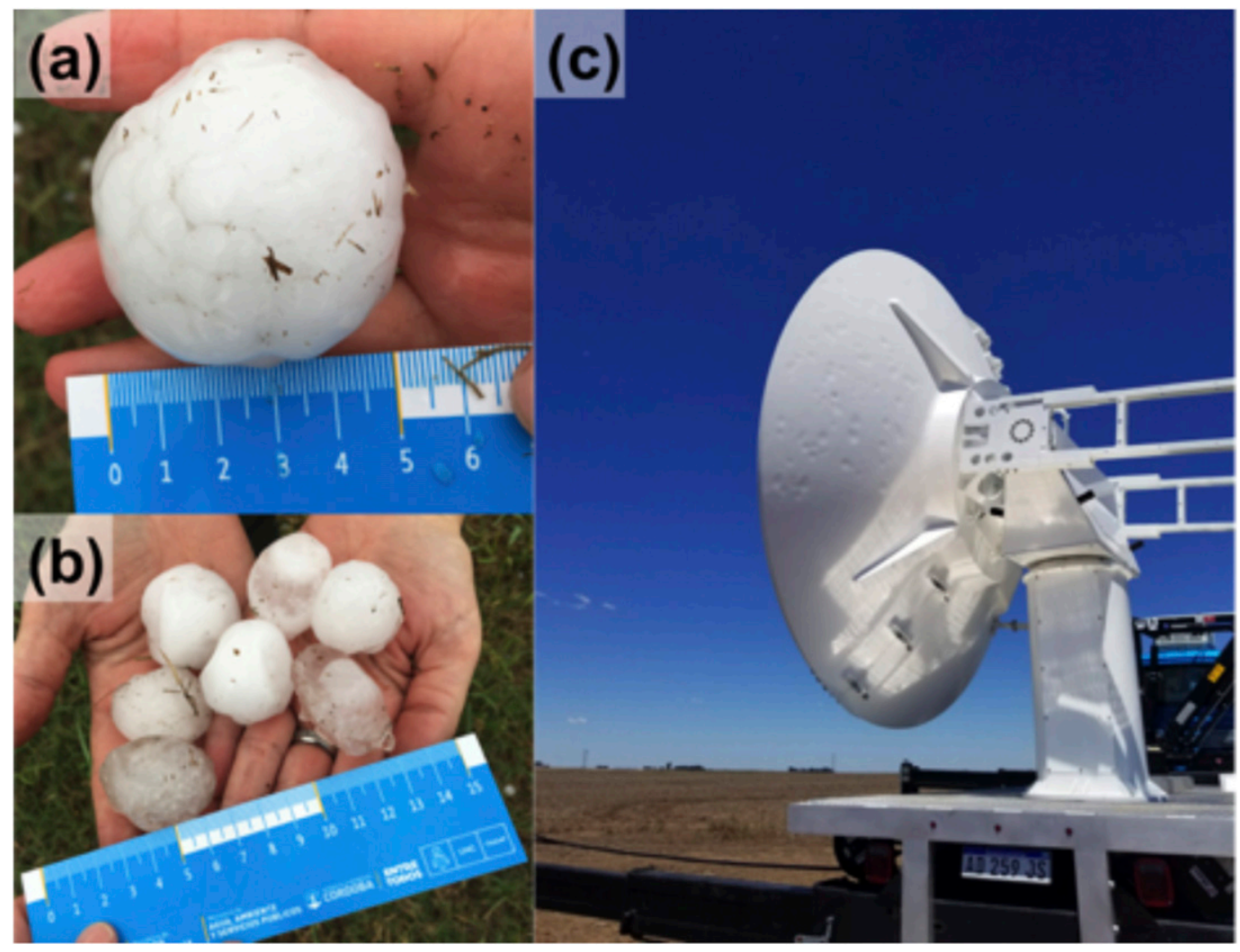

FIG. 10. (a),(b) Photographs of hailstones collected at the COW site taken at 2037 UTC 10 Nov 2018 (courtesy of Lorena Medina Luna, used with permission). (c) Photograph of the damaged COW antenna taken the following day (courtesy of Joshua Wurman). 


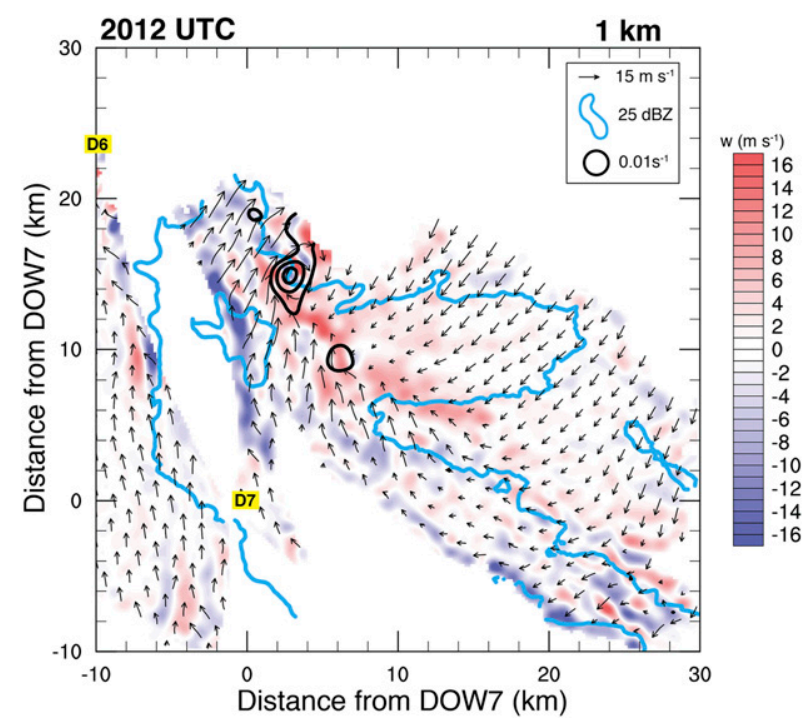

FIG. 11. Dual-Doppler analysis based on the DOW6 and DOW7 radars at 2012 UTC. Arrows are the ground-relative horizontal winds; color shading is the vertical velocity; black contours are vertical vorticity starting at $0.01 \mathrm{~s}^{-1}$, in increments of $0.01 \mathrm{~s}^{-1}$; and the cyan contour is the $25-\mathrm{dBZ}$ isopleth. The locations of DOW6 and DOW7 are labeled D6 and D7, respectively.

mismatched in time. This would impact the retrieval of rapidly evolving features such as the subkilometer-scale vortices, but these are not well resolved in the analyses.

Despite significant attenuation of the X-band signals in the heavy precipitation and hail, much of the storm structure is represented. At 2012 UTC, which was near the time the supercell was most intense, dual-Doppler analyses at low levels (1 km AGL) resolve the gust front and other mesoscale features (Fig. 11). Of particular interest are two subkilometer-scale (i.e., "tornado-scale") vortices observed along a shear line/gust front (Fig. 11). The formation of these vortices at $\sim 2003$ UTC appears to be linked to the shear line/gust front, given the absence of a distinct low-level mesocyclone and also of supportive low-level environmental shear. At 2005 UTC, the difference between the maximum and minimum Doppler velocity across one of these vortices was $\sim 36 \mathrm{~m} \mathrm{~s}^{-1}$, just below the $40 \mathrm{~m} \mathrm{~s}^{-1}$ threshold defined for tornadoes by Wurman and Kosiba (2013), and this intensity was maintained through $\sim 2012$ UTC. No visual manifestation of a tornado or damage (other than from hail) was reported by the RELAMPAGO field teams, however, and we are unaware of any public reports of a tornado or tornado damage. These vortices dissipated $\sim 2018$ UTC, and thus had a total duration of $\sim 15 \mathrm{~min}$.

Dual-Doppler analyses at $3 \mathrm{~km}$ AGL reveal the midlevel structure, and the rapid mesocyclone development and demise. For example, at 1951 UTC weak negative vertical vorticity $\left(-0.005 \mathrm{~s}^{-1}\right)$ resides in a broad updraft (Fig. 12a). By 2012 UTC, the vertical vorticity has increased to mesocyclone strength $\left(\left|-0.01 \mathrm{~s}^{-1}\right|\right)$ (e.g., Brandes 1978), and corresponds spatially to a more concentrated updraft (Fig. 12b). Shortly thereafter, by 2021 UTC, the somewhat weakened vertical vorticity now resides in a downdraft, which signals a demise of the midlevel mesocyclone (Fig. 12c).

One of our original hypotheses for this relatively short supercell duration is that the surface cold pools quickly become strongly negatively buoyant and "undercut" the updraft. MM transects (Fig. 4) indicate that the cold pool during IOP4 had a virtual potential temperature deficit of $\sim 4-8 \mathrm{~K}$, depending on precisely where and when the cold pool was sampled. These are consistent with cold pools in nontornadic supercells observed within the U.S. Great Plains (Markowski et al. 2002) as well as in MCSs observed within Oklahoma (Engerer et al. 2008), thereby suggesting that the IOP4 cold pool was not anomalously strong. Nevertheless, one challenge in evaluating our hypothesis here is that a cold pool preexisted-and even appeared to help lift air parcels toward the initiation of-this storm (Fig. 6). Idealized numerical simulations are underway to test the sensitivity of the convective evolution to this preexisting cold pool (I. Singh 2020, personal communication).

Another one of our original hypotheses is that the vertical wind shear (S06) is enhanced in an $\sim 50-100 \mathrm{~km}$ corridor near the SDC, and thus is especially supportive of supercell occurrence within this corridor. Environmental soundings collected during IOP4 lend some support to this hypothesized role of the terrain in locally modifying the environment. Figure 13a provides a representation of S06 across six sounding sites at 1800 UTC, and clearly shows a west-east decrease in S06. MLCAPE near the SDC has more west-east variability (Fig. 13b), although MLCAPE enhancements within $\sim 70 \mathrm{~km}$ east of the SDC are generally apparent. When accounting for the combined influences of the environmental winds and thermodynamics, a supercell morphology would be supported best (e.g., Thompson et al. 2003) in the environments represented at the DOE, MM2, UIUC2, and CSU sites indicated in Fig. 13, and thus in a narrow corridor near the SDC. Consistently, the WRF modeling experiments conducted by Mulholland et al. (2019) indicate similar environmental gradients eastward from the SDC (e.g., their Fig. 5), and moreover find that these gradients are increased when the height of the SDC is artificially increased. ${ }^{2}$

\footnotetext{
${ }^{2}$ See also Rasmussen and Houze (2016) for similar results in experiments with the Andes Mountains.
} 

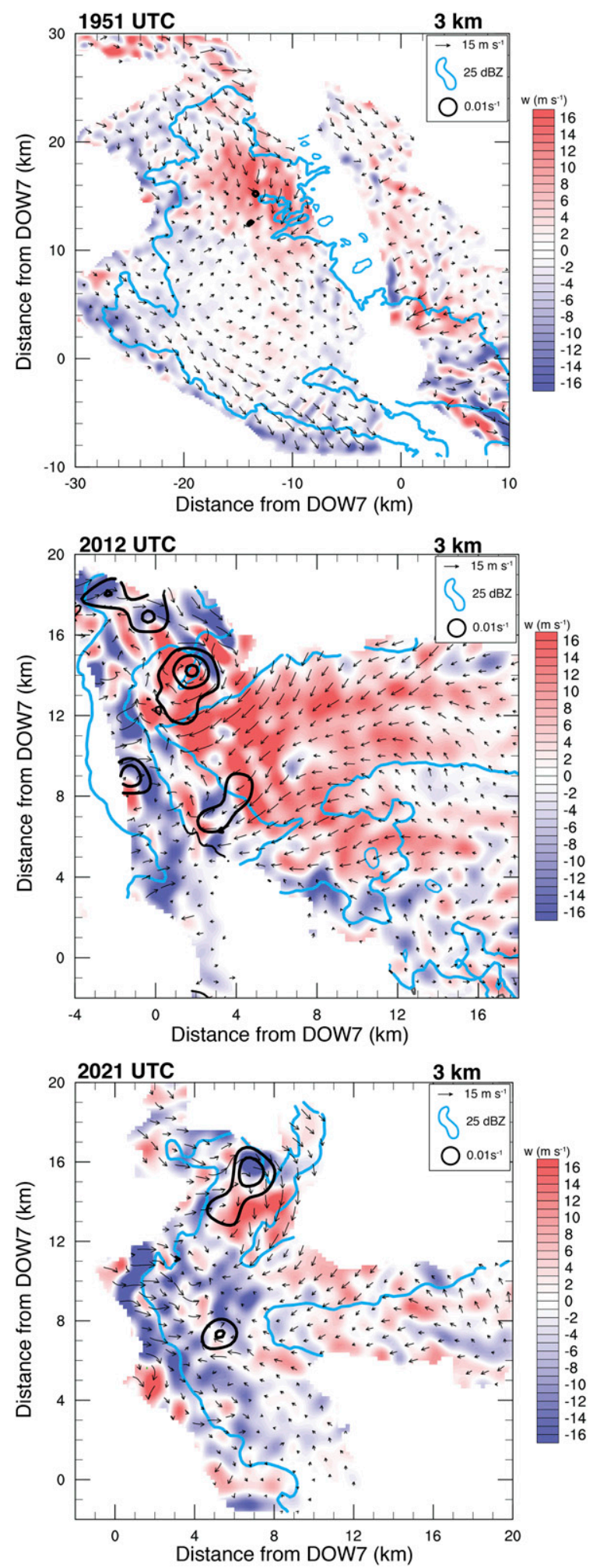

FIG. 12. As in Fig. 11, but at $3 \mathrm{~km}$ AGL, and at (a) 1951, (b) 2012, and (c) 2021 UTC. At 1951 UTC, vertical vorticity is negligible at $3 \mathrm{~km}$. Note that (b) and (c) are smaller domains.
Additional insight into terrain-induced environmental enhancements on supercells can be drawn from Soderholm et al. (2014). Using modeling experiments with an idealized mountain similar in height to that of the SDC, Soderholm et al. (2014) found that simulated supercells were more sensitive to vertical wind shear perturbations due to the terrain than to the thermodynamic perturbations. In their study, the wind shear perturbations were dynamically induced on the leeside of the terrain feature, as were mesoscale vertical vorticity perturbations in the study by Markowski and Dotzek (2011); consequently, increases in supercell rotation occurred on the leeside in the respective simulations. Wind shear perturbations can also be induced near the terrain by anabatic, or thermally driven upslope flow. The upslope flow results in a zone of horizontal vorticity (e.g., Geerts et al. 2008) surrounding the terrain, which therefore can be realized as zones of enhanced S06 and SRH (Mulholland et al. 2019). In the case of the SDC, with low-level northerly flow on the leeside, a left-moving supercell updraft encountering such zones would tilt upward antistreamwise horizontal vorticity, thus resulting in midlevel clockwise rotation. The subsequent rotational dynamics (e.g., see Trapp 2013) can promote supercell intensity and longevity, but this requires continued residence in this terraininduced favorable environment. The relatively short duration of the IOP4 supercell appears to reflect its relatively short residence in the enhanced environment. However, the documented existence of supercells well east of the SDC (Mulholland et al. 2018) suggests that this likely is a sufficient but not necessary condition.

\section{Other supercell examples over the Córdoba Province}

To provide some context for the IOP4 supercell duration, radar data from RMA1 are used here to document the occurrence and longevity of a sample of recent supercellular storms over the Córdoba Province. Our specific focus is on the duration of the midlevel ( $\sim 3-$ $5 \mathrm{~km}$ AGL) mesocyclone, which is identified where and when the maximum differential velocity exceeds $10 \mathrm{~m} \mathrm{~s}^{-1}$ (Smith et al. 2012). Note that this Doppler velocity criterion avoids possible misinterpretations that may arise from a consideration of radar reflectivity alone. Four storms are considered: 29 November 2017, which occurred during the RELAMPAGO "dry run" (DR); 8 February 2018, which generated hail $>15 \mathrm{~cm}$ in maximum dimension (i.e., gargantuan hail) in Villa Carlos Paz (Kumjian et al. 2020); 13 December 2018, which corresponds to RELAMPAGO IOP17; and 25 January 2019, 


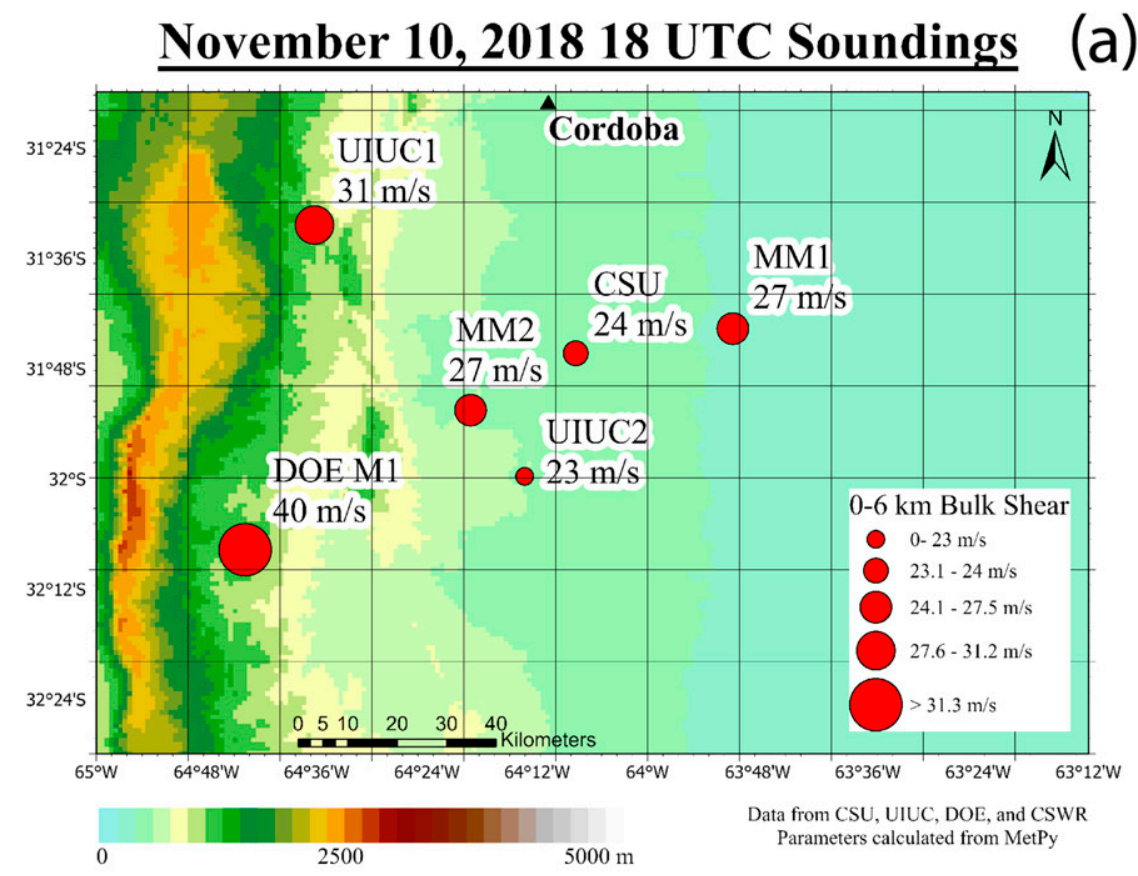

November 10, 201818 UTC Soundings (b)

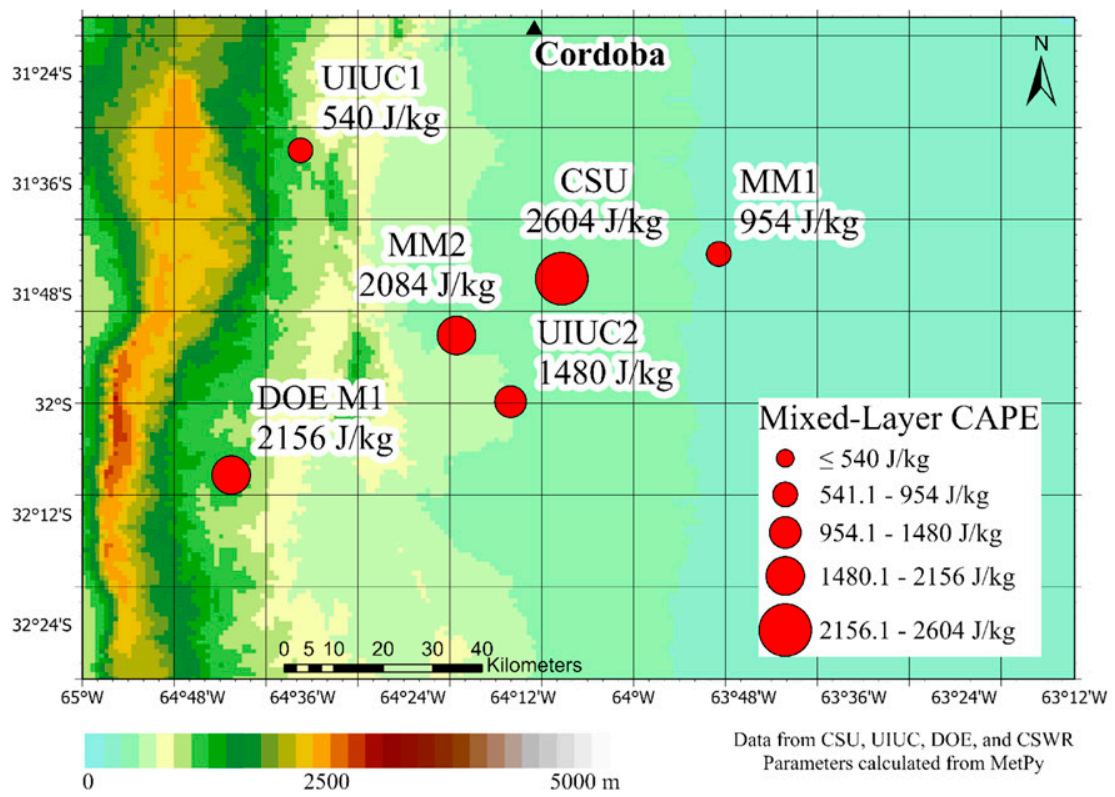

FIG. 13. Representation of (a) S06 $\left(\mathrm{m} \mathrm{s}^{-1}\right)$ and (b) MLCAPE $\left(\mathrm{J} \mathrm{kg}^{-1}\right)$ across six RELAMPAGO sounding sites at 1800 UTC 10 Nov 2018.

which occurred during the RELAMPAGO-CACTI extended observing period (EOP) (Fig. 14).

Table 1 summarizes the midlevel mesocyclone durations, which range from 25 to $93 \mathrm{~min}$; for reference, the duration of the IOP4 mesocyclone was $25 \mathrm{~min}$. It is noteworthy that the durations for all but the 8 February 2018 case were less than the 60-min mean duration of mesocyclones observed in Oklahoma (Wood et al. 1996). It is also noteworthy that in each of these cases, the actual storm persisted well beyond mesocyclone demise, usually in the form of an MCS after undergoing upscale growth.

Although an array of soundings eastward from the SDC is not available for these cases as it was for IOP4, CAM forecasts and simulations indicate that west-east gradients 
RMA-1 1.5 Deg. 2017-11-29T19:13:12Z

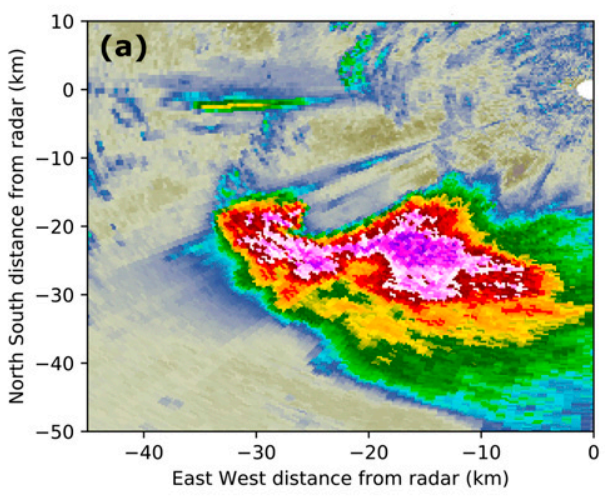

CSU-CHIVO 1.3 Deg. 2018-12-13T23:51:03Z

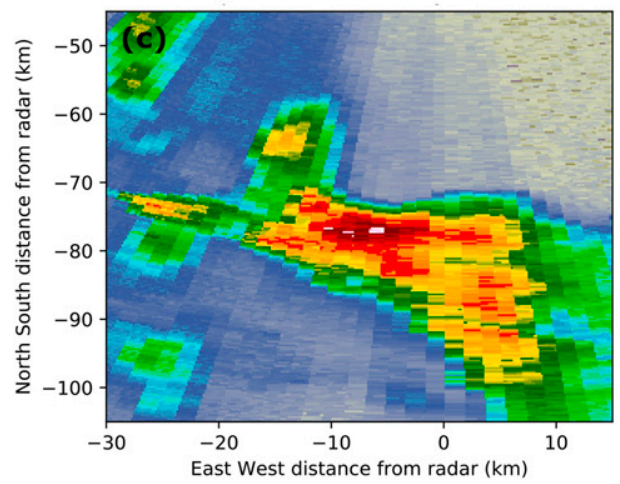

RMA-1.5 Deg. 2018-02-08T19:24:28Z

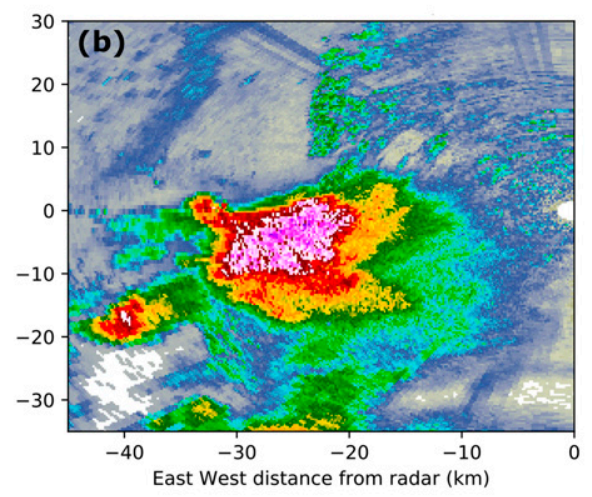

CSU-CHIVO 1.5 Deg. 2019-01-25T19:00:29Z

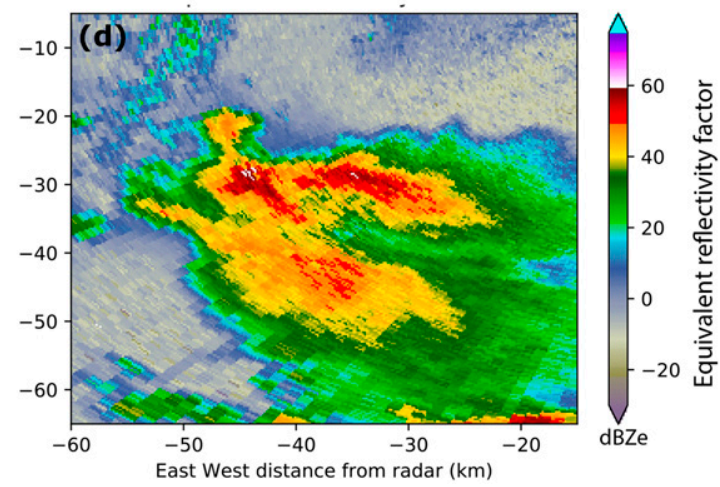

FIG. 14. Equivalent radar reflectivity $\left(\mathrm{dB} Z_{e}\right)$ in PPI scans of supercells in the Córdoba Province at (a) 1913: 12 UTC 29 Nov 2017, (b) 1924:28 UTC 8 Feb 2018, (c) 2351:03 UTC 13 Dec 2018, and (d) 1900:29 UTC 25 Jan 2019. In (a),(b), the scans are at $1.5^{\circ}$ elevation from RMA1, and in (c),(d) the scans are from the CSU C-band radar at $1.3^{\circ}$ and $1.5^{\circ}$ elevation, respectively.

in S06, MLCAPE, and other environmental convective parameters are a consistent feature (e.g., Mulholland et al. 2019, their Fig. 5). The mesocyclone durations appear to depend at least in part on the length of time the storms reside within the terrain-enhanced environment, and thus on the supercell motions. Using the Bunkers et al. (2000) technique, the estimated left-moving supercell motion on 8 February 2018 is nearly parallel to the long axis of the SDC, while on 10 November 2018 and 13 December 2018 the supercell motion is nearly perpendicular to the long axis of the SDC (Table 1). The supercell motions on 28 November 2017 and 25 January 2019 are more oblique to the SDC. All of these estimated motions are in general agreement with radar databased assessments. Consistently, the supercell on 8 February 2018 had a mesocyclone duration of $91 \mathrm{~min}$, while on 10 November 2018 and 13 December 2018 the mesocyclone durations were $25 \mathrm{~min}$, and on 28 November 2017 and 25 January 2019 the mesocyclone durations were 41 and $51 \mathrm{~min}$, respectively (Table 1 ). The documented tendency for a relatively fast transition from nascent convective storm to MCS in this region (Mulholland et al. 2018) seems to suggest that SDC-perpendicular supercell motions are more common.

An additional consideration for the explanation of this tendency is the known increase in horizontal size or

TABLE 1. Midlevel mesocyclone duration based on Doppler velocity from RMA1, and the components $(u, v)$ of the left-moving (LM) supercell motion estimated from an environmental sounding and application of the Bunkers et al. (2000) method.

\begin{tabular}{lcc}
\hline \hline Date/case & Midlevel mesocyclone duration (min) & $\begin{array}{c}\text { Bunkers's LM supercell motion } \\
\text { components }\left(\mathrm{m} \mathrm{s}^{-1}\right)\end{array}$ \\
\hline 29 Nov 2017 & 41 & $(10.8,-4.5)$ \\
8 Feb 2018 & 93 & $(-7.8,13.0)$ \\
13 Dec 2018 & 25 & $(17.8,1.0)$ \\
25 Jan 2019 & 51 & $(4.0,8.6)$ \\
\hline
\end{tabular}


area of a supercell updraft with increases in deep-layer vertical wind shear (Kirkpatrick et al. 2009; Trapp et al. 2017; Dennis and Kumjian 2017; Marion and Trapp 2019): as demonstrated by Marion and Trapp (2019), this updraft width-vertical shear relationship owes to the critical dependence of the linear and nonlinear dynamics forcing of vertical accelerations on vertical shear. Note that because wide updrafts provide larger volumes for hail growth (e.g., Dennis and Kumjian 2017), an updraft-width enhancement by the terrain-enhanced vertical wind shear may have contributed to the large hail on 10 November 2018 despite the relatively short duration of updraft rotation in the IOP4 storm; future work will explore this possible connection. Wide supercell updrafts also lead to wide downdrafts and deep cold pools (Marion and Trapp 2019), which in turn promote relatively fast upscale growth (Mulholland et al. 2020). Indeed, idealized modeling experiments by Mulholland et al. (2020) demonstrate that increases in terrain lead to faster upscale growth through this connection between terrain-enhanced vertical wind shear, updraft width, and cold-pool depth. The interplay between this effect of terrain-enhanced shear and that associated with the rotational dynamics awaits future analysis.

\section{Summary and conclusions}

Evidence based on multiple observations from RELAMPAGO has been presented in support of the categorization of an intense convective storm as a supercell. This evidence includes a high spatial correspondence between midlevel vertical velocity and vertical vorticity, as provided through the retrieval of $3 \mathrm{D}$ winds from dual-Doppler radar scans; this, incidentally, is the first dual-Doppler radar dataset ever collected on a supercell in South America. Our supercell categorization could be considered questionable, given the $\sim 25$-min duration of the midlevel mesocyclone. Indeed, this is considered brief, especially relative to the $60-\mathrm{min}$ mean duration of mesocyclones in Oklahoma supercells (Wood et al. 1996), and also to the accepted conceptual model and definition (American Meteorological Society 2020). It appears that such a short duration could be intimately linked to the local terrain (Mulholland et al. 2019).

Specifically, the IOP4 supercell and other short-duration supercell cases presented herein all had storm motions that were nearly perpendicular to the long axis of the SDC; the long-duration supercell case, on the other hand, had a storm motion nearly parallel to the SDC. RELAMPAGO sounding observations as well as WRF Model simulations indicate that a mountain-perpendicular storm motion results in a relatively short storm residence time within the narrow zone of terrain-enhanced vertical wind shear.
Such a motion and short residence time would limit the upward tilting, by the left-moving supercell updraft, of the storm-relative, antistreamwise horizontal vorticity associated with anabatic flow.

Future work will explore the consequential limits on supercell longevity due to the reduced rotational dynamics, and will compare this effect with the effect of terrain-enhanced shear on updraft width and associated promotion of upscale growth. More generally, a further comparison of the IOP4 supercell with additional cases that are well sampled by Doppler radar, and have wellsampled environmental conditions, will help us determine the representativeness of the IOP4 storm to the larger population of convective storms in that region.

Acknowledgments. This work was supported in part by the National Science Foundation (NSF) Grants AGS1661800 (Trapp and Hence), AGS-1661548 (Kosiba and Wurman), AGS-1661707 (Marquis), AGS-1661679 (Kumjian), AGS-1661799 (Nesbitt); the U.S. Department of Energy Atmospheric System Research (Marquis); and Argentinean projects PICT 2017-0221, PICT 2016-0710 and UBACyT 20020170100164BA (Salio). The Secretaria de Politicas Universitarias Res 2018-29 and INVAP S.E. is thanked for their contributions to participate in the field campaign. The CSWR DOW facility is part of the NSF LAOF and is funded by AGS-1361237. CACTI instrumentation is supported by the Atmospheric Radiation Measurement program. RMA1 data were provided by Secretaría de Infraestructura y Política Hídrica, Ministerio del Interior, Obras Públicas y Vivienda of the Argentinean National Government framed within the SINARAME Project, which is an Argentinean effort to expand the radar network over the whole country. The Python ARM Radar Toolkit (http://doi.org/10.5334/jors.119) was used to create some of the figures. A large team consisting of researchers, operational and research forecasters, instrument crews and technical staff, various government agencies and academic institutions in Argentina, and the supportive residents of the observational domain were critical to making this IOP and other data collection during RELAMPAGO a success. Comments and suggestions made by the three anonymous reviewers of this manuscript helped improve the description and meteorological importance of the IOP4 data.

\section{REFERENCES}

American Meteorological Society, 2020: Supercell. Glossary of Meteorology, http://glossary.ametsoc.org/wiki/Supercell.

Atmospheric Radiation Measurement (ARM) User Facility, 2018a: Balloon-Borne Sounding System (SONDEWNPN) (updated hourly). ARM Mobile Facility (COR) Cordoba, Argentina; AMF1 (main site for CACTI) (M1),ARM Data Center, accessed 1 May 2019, https://doi.org/10.5439/1021460. 
, 2018b: C-Band Scanning ARM Precipitation Radar (CSAPR2CFRHSRHI, CSAPR2CFRPPI) (updated hourly). ARM Mobile Facility (COR) Cordoba, Argentina; AMF1 (main site for CACTI) (M1),ARM Data Center, accessed 1 May 2019, https://doi.org/10.5439/1482619.

Bang, S. D., and D. J. Cecil, 2019: Constructing a multifrequency passive microwave hail retrieval and climatology in the GPM domain. J. Appl. Meteor. Climatol., 58, 1889-1904, https:// doi.org/10.1175/JAMC-D-19-0042.1.

Blair, S. F., and Coauthors, 2017: High-resolution hail observations: Implications for NWS warning operations. Wea. Forecasting, 32, 1101-1119, https://doi.org/10.1175/WAF-D-16-0203.1.

Blyth, A. M., S. G. Lasher-Trapp, and W. A. Cooper, 2005: A study of thermals in cumulus clouds. Quart. J. Roy. Meteor. Soc., 131, 1171-1190, https://doi.org/10.1256/QJ.03.180.

Brandes, E. A., 1978: Mesocyclone evolution and tornadogenesis: Some observations. Mon. Wea. Rev., 106, 995-1011, https://doi.org/ 10.1175/1520-0493(1978)106<0995:MEATSO > 2.0.CO;2.

Bruick, Z. S., K. L. Rasmussen, and D. J. Cecil, 2019: Subtropical South American hailstorm characteristics and environments. Mon. Wea. Rev., 147, 4289-4304, https://doi.org/10.1175/ MWR-D-19-0011.1.

Bunkers, M. J., B. A. Klimowski, J. W. Zeitler, R. L. Thompson, and M. L. Weisman, 2000: Predicting supercell motion using a new hodograph technique. Wea. Forecasting, 15, 61-79, https://doi.org/10.1175/1520-0434(2000)015<0061: PSMUAN $>2.0 . \mathrm{CO} ; 2$.

Cecil, D., and C. Blankenship, 2012: Toward a global climatology of severe hailstorms as estimated by satellite passive microwave imagers. J. Climate, 25, 687-703, https://doi.org/10.1175/ JCLI-D-11-00130.1.

Chisholm, A. J., and J. H. Renick, 1972: The kinematics of multicell and supercell Alberta hailstorms. Alberta hail studies, Research Council of Alberta Hail Studies, Rep. 72-2, 24-31.

Damiani, R., G. Vali, and S. Haimov, 2006: The structure of thermals in cumulus from airborne dual-Doppler radar observations. J. Atmos. Sci., 63, 1432-1450, https://doi.org/ 10.1175/JAS3701.1.

Dennis, E., and M. R. Kumjian, 2017: The impact of vertical wind shear on hail growth in simulated supercells. J. Atmos. Sci., 74, 641-663, https://doi.org/10.1175/JAS-D-16-0066.1.

Engerer, N. A., D. J. Stensrud, and M. C. Coniglio, 2008: Surface characteristics of observed cold pools. Mon. Wea. Rev., 136, 4839-4849, https://doi.org/10.1175/2008MWR2528.1.

Geerts, B., Q. Miao, and J. C. Demko, 2008: Pressure perturbations and upslope flow over a heated, isolated mountain. Mon. Wea. Rev., 136, 4272-4288, https://doi.org/10.1175/2008MWR2546.1.

Kirkpatrick, C., E. W. McCaul Jr, and C. Cohen, 2009: Variability of updraft and downdraft characteristics in a large parameter space study of convective storms. Mon. Wea. Rev., 137, 15501561, https://doi.org/10.1175/2008MWR2703.1.

Klemp, J. B., and R. B. Wilhelmson, 1978: Simulations of rightand left-moving storms produced through storm splitting. J. Atmos. Sci., 35, 1097-1110, https://doi.org/10.1175/15200469(1978)035<1097:SORALM > 2.0.CO;2.

Kosiba, K., J. Wurman, Y. Richardson, P. Markowski, P. Robinson, and J. Marquis, 2013: Genesis of the Goshen County, Wyoming, Tornado on 5 June 2009 during VORTEX2. Mon. Wea. Rev., 141, 1157-1181, https://doi.org/10.1175/MWR-D-12-00056.1.

Krupar, R. J., III, M. S. Mason, D. J. Smith, J. Soderholm, A. Protat, and W. S. Gunter, 2017: Dual-Doppler radar, in situ anemometric and ground damage observations of the 27 November 2014 Brisbane supercell. Preprints, 13th
Americas Conf. on Wind Engineering (13ACWE), Gainesville, FL, University of Florida, XX-XX.

Kumjian, M. R., and A. V. Ryzhkov, 2008: Polarimetric signatures in supercell thunderstorms. J. Appl. Meteor. Climatol., 47, 1940-1961, https://doi.org/10.1175/2007JAMC1874.1.

_ Z. Lebo, and A. Ward, 2019: Storms producing large accumulations of small hail. J. Appl. Meteor. Climatol., 58, 341364, https://doi.org/10.1175/JAMC-D-18-0073.1.

— , and Coauthors, 2020: Gargantuan hail in Argentina. Bull. Amer. Meteor. Soc., https://doi.org/10.1175/BAMS-D-19-0012.1, in press.

Majcen, M., P. Markowski, Y. Richardson, D. Dowell, and J. Wurman, 2008: Multipass objective analyses of Doppler radar data. J. Atmos. Oceanic Technol., 25, 1845-1858, https:// doi.org/10.1175/2008JTECHA1089.1.

Marion, G. R., and R. J. Trapp, 2019: The dynamical coupling of convective updrafts, downdrafts, and cold pools in simulated supercell thunderstorms. J. Geophys. Res. Atmos., 124, 664683, https://doi.org/10.1029/2018JD029055.

$\longrightarrow, \ldots$, and S. W. Nesbitt, 2019: Using overshooting top area to discriminate potential for large, intense tornadoes. Geophys. Res. Lett., 46, 12 520-12 526, https://doi.org/10.1029/2019GL084099.

Markowski, P. M., and N. Dotzek, 2011: A numerical study of the effects of orography on supercells. Atmos. Res., 100, 457-478, https://doi.org/10.1016/j.atmosres.2010.12.027.

_ J. M. Straka, and E. N. Rasmussen, 2002: Direct surface thermodynamic observations within the rear-flank downdrafts of nontornadic and tornadic supercells. Mon. Wea. Rev., 130, 1692-1721, https://doi.org/10.1175/1520-0493(2002)130<1692: DSTOWT $>2.0 . \mathrm{CO} ; 2$.

Mezher, R. N., M. Doyle, and V. Barros, 2012: Climatology of hail in Argentina. Atmos. Res., 114-115, 70-82, https://doi.org/ 10.1016/j.atmosres.2012.05.020.

Morrison, H., 2017: An analytic description of the structure and evolution of growing deep cumulus updrafts. J. Atmos. Sci., 74, 809-834, https://doi.org/10.1175/JAS-D-16-0234.1.

Mulholland, J. P., S. W. Nesbitt, R. J. Trapp, K. L. Rasmussen, and P. V Salio, 2018: Convective storm life cycle and environments near the Sierras de Córdoba, Argentina. Mon. Wea. Rev., 146, 2541-2557, https://doi.org/10.1175/MWR-D-18-0081.1.

,-- , and -2019 : A case study of terrain influences on upscale convective growth of a supercell. Mon. Wea. Rev., 147, 4305-4324, https://doi.org/10.1175/MWR-D-19-0099.1.

,,,--- and J. M. Peters, 2020: The influence of terrain on the convective environment and associated convective morphology from an idealized modeling perspective. J. Atmos. Sci., https://doi.org/10.1175/JAS-D-19-0190.1, in press.

Nesbitt, S. W., and Coauthors, 2016: RELAMPAGO Experimental Design Overview. Accessed 15 April 2020, https://www.eol. ucar.edu/field_projects/relampago.

Rasmussen, K. L., and R. A. Houze, 2016: Convective initiation near the Andes in subtropical South America. Mon. Wea. Rev., 144, 2351-2374, https://doi.org/10.1175/MWR-D-15-0058.1.

—, M. D. Zuluaga, and R. A. Houze, 2014: Severe convection and lightning in subtropical South America. Geophys. Res. Lett., 41, 7359-7366, https://doi.org/10.1002/2014GL061767.

Ryzhkov, A. V., M. R. Kumjian, S. M. Ganson, and A. P. Khain, 2013: Polarimetric radar characteristics of melting hail. Part I: Theoretical simulations using spectral microphysical modeling. J. Appl. Meteor. Climatol., 52, 2849-2870, https://doi.org/ 10.1175/JAMC-D-13-073.1.

Salio, P., M. Nicolini, and A. C. Saulo, 2002: Chaco low-level jet events characterization during the austral summer season. J. Geophys. Res., 107, 4816, https://doi.org/10.1029/2001JD001315. 
Seluchi, M. E., A. C. Saulo, M. Nicolini, and P. Satyamurty, 2003: The northwestern Argentinean low: A study of two typical events. Mon. Wea. Rev., 131, 2361-2378, https://doi.org/ 10.1175/1520-0493(2003)131<2361:TNALAS > 2.0.CO;2.

Skamarock, W. C., and Coauthors, 2008: A description of the Advanced Research WRF version 3. NCAR Tech. Note NCAR/TN 475+STR, 113 pp., https://doi.org/10.5065/D68S4MVH.

_ , J. B. Klemp, M. G. Duda, L. D. Fowler, S.-H. Park, and T. D. Ringler, 2012: A multiscale nonhydrostatic atmospheric model using centroidal Voronoi tesselations and C-grid staggering. Mon. Wea. Rev., 140, 3090-3105, https:// doi.org/10.1175/MWR-D-11-00215.1.

Smith, B. T., R. L. Thompson, J. S. Grams, C. Broyles, and H. E. Brooks, 2012: Convective modes for significant severe thunderstorms in the contiguous United States. Part I: Storm classification and climatology. Wea. Forecasting, 27, 1114-1135, https://doi.org/10.1175/ WAF-D-11-00115.1.

Soderholm, B., B. Ronalds, and D. J. Kirshbaum, 2014: The evolution of convective storms initiated by an isolated mountain ridge. Mon. Wea. Rev., 142, 1430-1451, https://doi.org/10.1175/ MWR-D-13-00280.1.

Soderholm, J., H. McGowan, H. Richter, K. Walsh, T. Weckwerth, and M. Coleman, 2016: The Coastal Convective Interactions Experiment (CCIE): Understanding the role of sea breezes for hailstorm hotspots in eastern Australia. Bull. Amer. Meteor. Soc., 97, 1687-1698, https://doi.org/10.1175/BAMS-D-14-00212.1.

Thompson, R. L., R. Edwards, J. A. Hart, K. L. Elmore, and P. Markowski, 2003: Close proximity soundings within supercell environments obtained from the Rapid Update Cycle. Wea. Forecasting, 18, 1243-1261, https://doi.org/10.1175/15200434(2003)018<1243:CPSWSE > 2.0.CO;2.

Trapp, R. J., 2013: Mesoscale-Convective Processes in the Atmosphere. Cambridge University Press, 346 pp.
G. R. Marion, and S. W. Nesbitt, 2017: The regulation of tornado intensity by updraft area. J. Atmos. Sci., 74, 41994211, https://doi.org/10.1175/JAS-D-16-0331.1.

Varble, A., and Coauthors, 2018: Cloud, Aerosol, and Complex Terrain Interactions (CACTI) Science Plan. DOE/ARM Tech. Rep. DOE/SC-ARM-17-004, 48 pp., https://www.arm.gov/ research/campaigns/amf2018cacti.

Weisman, M. L., and J. B. Klemp, 1982: The dependence of numerically simulated convective storms on vertical wind shear and buoyancy. Mon. Wea. Rev., 110, 504-520, https://doi.org/ 10.1175/1520-0493(1982)110<0504:TDONSC >2.0.CO;2.

Wood, V. T., R. A. Brown, and D. W. Burgess, 1996: Duration and movement of mesocyclones associated with Southern Great Plains thunderstorms. Mon. Wea. Rev., 124, 97-101, https://doi.org/ 10.1175/1520-0493(1996)124<0097:DAMOMA>2.0.CO;2.

Wurman, J., 2001: The DOW mobile multiple Doppler network. Preprints, 30th Int. Conf. on Radar Meteorology, Munich, Germany, Amer. Meteor. Soc., 95-97.

— , and K. Kosiba, 2013: Finescale radar observations of tornado and mesocyclone structures. Wea. Forecasting, 28, 1157-1174, https://doi.org/10.1175/WAF-D-12-00127.1.

—- J. M. Straka, E. Rasmussen, M. Randall, and A. Zahrai, 1997: Design and deployment of a portable, pencil-beam, pulsed, 3-cm Doppler radar. J. Atmos. Oceanic Technol., 14, 1502-1512, https://doi.org/10.1175/1520-0426(1997)014<1502: DADOAP $>2.0 . \mathrm{CO} ; 2$.

Zhao, M., and P. H. Austin, 2005: Life cycle of numerically simulated shallow cumulus clouds. Part II: Mixing dynamics. J. Atmos. Sci., 62, 1291-1310, https://doi.org/10.1175/JAS3415.1.

Zipser, E. J., D. J. Cecil, C. T. Liu, S. W. Nesbitt, and D. P. Yorty, 2006: Where are the most intense thunderstorms on Earth? Bull. Amer. Meteor. Soc., 87, 1057-1072, https://doi.org/ 10.1175/BAMS-87-8-1057. 